\title{
Mira Xenia Schwerda. « Mirza Riza Kirmani, Prison Portraiture and the Depiction of Public Executions in Qajar Iran »
}

\section{Iván Szántó}

\section{(2) OpenEdition Journals}

Electronic version

URL: http://journals.openedition.org/abstractairanica/42746

DOI: 10.4000/abstractairanica.42746

ISBN: 1961-960X

ISSN: 1961-960X

Publisher:

CNRS (UMR 7528 Mondes iraniens et indiens), Éditions de l'IFRI

\section{Electronic reference}

Iván Szántó, « Mira Xenia Schwerda. « Mirza Riza Kirmani, Prison Portraiture and the Depiction of

Public Executions in Qajar Iran » », Abstracta Iranica [Online], Volume 37-38-39 | 2018, document 16, Online since 10 March 2018, connection on 27 September 2020. URL : http://journals.openedition.org/ abstractairanica/42746 ; DOI : https://doi.org/10.4000/abstractairanica.42746

This text was automatically generated on 27 September 2020 .

Tous droits réservés 


\title{
Mira Xenia Schwerda. « Mirza Riza Kirmani, Prison Portraiture and the Depiction of Public Executions in Qajar Iran »
}

\author{
Iván Szántó
}

\section{REFERENCES}

Mira Xenia Schwerda. « Mirza Riza Kirmani, Prison Portraiture and the Depiction of Public Executions in Qajar Iran ", Middle East Journal of Culture and Communication, 8/2-3 (2015), p. 172-191, 6 figs.

1 The article analyses a series of photographs depicting Mīrzā Rezāa Kermānī, the assassin of Nāser al-Dīn shah, first imprisoned, then executed (on 11 August 1896). These photographs were taken by a number of official photographers from different angles and distances, and widely disseminated in various forms in order to use the imagery as a deterrent by imprinting the face of the regicide and his punishment on collective consciousness. This may have been among the first instances when photographs were employed to influence public sentiment in Iran. As the author demonstrates, the effects of this novel publicity were grossly miscalculated by the state: whereas the photographs were circulated to condemn the perpetrator, some viewers quickly started to regard them as the depictions of a martyr facing oppression. This led to frequent reappearances of the prints in various newspapers and pamphlets during the constitutional period, foretelling $20^{\text {th }}$-century struggles for control over mass media. 


\section{AUTHORS}

IVÁN SZÁNTÓ

Eötvös Loránd University, Budapest \& Austrian Academy of Sciences, Vienne 